\title{
BULLETIN
}

O F

\section{ENTOMOLOGICAL RESEARCH}

\author{
VOL. 71
}

ISSUED BY THE COMMONWEALTH

INSTITUTE OF ENTOMOLOGY

EDITOR: THE DIRECTOR

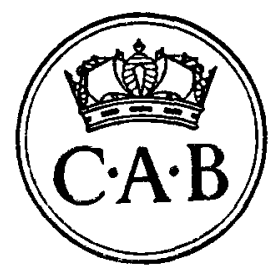

\section{LONDON}

Commonwealth Institute of Entomology

56, Queen's Gate, SW7 5JR

1981 


\title{
COMMONWEALTH INSTITUTE OF ENTOMOLOGY
}

\author{
Director and Editor \\ N. C. PANT, M.Sc., Ph.D., D.I.C., F.N.A.
}

Assistant Director

A. H. Parker, M.Sc., Ph.D.

Assistant Editor

J. M. B. Harley, B.Sc.

Headquarters, Publication Office and Library-56 Queen's Gate, London SW7 5JR, UK. Telephone: 01-584-0067. Telegrams: ENTINFo LoNDON SW7.

Identification Service-c/o British Museum (Natural History), Cromwell Road, London SW7 5BD, UK.

The Commonwealth Institute of Entomology is one of 10 Bureaux and 4 Institutes that together form the Commonwealth Agricultural Bureaux, an organisation sponsored by the Commonwealth governments for the dissemination of information on agricultural research.

The Bulletin of Entomological Research is a quarterly journal prepared by the Institute and published by the Commonwealth Agricultural Bureaux.

\section{Annual Subscription Rate}

To subscribers in countries that are members of CAB $£ 42.00$

To subscribers in countries that are not members of CAB $\quad £ 65.00$

Back Numbers

Back volumes of the Bulletin of Entomological Research are available and there are discounts up to a maximum of $50 \%$ on orders of more than 10 volumes.

Orders and enquiries concerning subscriptions and back numbers should be sent to

CENTRAL SALES,

COMMONWEALTH AGRICULTURAL BUREAUX, FARNHAM ROYAL, SLOUGH SL2 3BN, UK.

[Note: Prices are subject to change without notice.]

(C) Commonwealth Agricultural Bureaux. 1981. All rights reserved. No part of this publication may be reproduced in any form or by any means, electronically, mechanically, by photo-copying, recording or otherwise, without the prior permission of the copyright owner.

The Executive Council of the Commonwealth Agricultural Bureaux is a signatory to the Fair Copying Declaration, details of which can be obtained from The Royal Society, 6 Carlton House Terrace, London S.W.1.

The Commonwealth Agricultural Bureaux organisation does not accept responsibility for any trade advertisement included in this publication. 


\section{CONTENTS}

\section{PART 1 MARch 1981}

Smith, P. H., Konovalov, C. A., Foster, G. G. \& Kerr, R. W. Assessment of the quality of mass-reared Lucilia cuprina (Wiedemann) (Diptera: Calliphoridae) males treated with dieldrin as larvae in a female-killing procedure

Briese, D. T. \& Mende, H. A. Differences in susceptibility to a granulosis virus between field populations of the potato moth, Phthorimaea

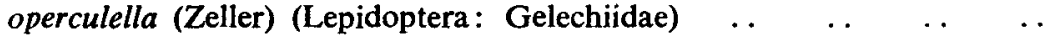

Pope, R. D. “Rhyzobius ventralis" (Coleoptera: Coccinellidae), its constituent species, and their taxonomy and historical roles in biological control ..

Richards, A. M. Rhyzobius ventralis (Erichson) and $R$. forestieri (Mulsant) (Coleoptera: Coccinellidae), their biology and value for scale insect control $\ldots \begin{array}{llllllllll}\text {. . } & \ldots & \ldots & \ldots & \ldots & \ldots & \ldots & \ldots & \ldots\end{array}$

Derr, J. A. Light-trap catches of Dysdercus bimaculatus Stål (Heteroptera: Pyrrhocoridae) in relation to weather and the fruiting cycle of its host-

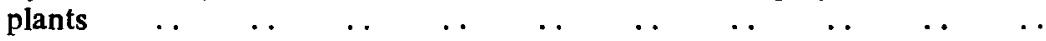

langley, P. A., Huyton, P. M., Carlson, D. A. \& Schwarz, M. Effects of Glossina morsitans morsitans Westwood (Diptera: Glossinidae) sex pheromone on behaviour of males in field and laboratory .. ..

Gillies, M. T. \& Wilkes, T. J. Field experiments with a wind tunnel on the flight speed of some West African mosquitoes (Diptera: Culicidae) .

Van Pletzen, R. \& VAn der Linde, T. C. DE K. Studies on the biology of Culiseta longiareolata (Macquart) (Diptera: Culicidae) .. $\quad . \quad$..

Rowcliffe, C. \& Finlayson, L. H. Factors influencing the selection of larviposition sites in the laboratory by Glossina morsitans morsitans Westwood (Diptera : Glossinidae) . . $\quad \ldots \quad$.

Nathan, M. B. Transmission of the human filarial parasite Mansonella ozzardi by Culicoides phlebotomus (Williston) (Diptera: Ceratopogonidae) in coastal north Trinidad ..

Bigger, M. Observations on the insect fauna of shaded and unshaded Amelonado $\begin{array}{lllllllllll}\text { cocoa } & \ldots & \ldots & \ldots & \ldots & \ldots & \ldots & \ldots & \ldots & \ldots & \ldots\end{array}$

Nathan, M. B. A study of the diurnal biting and flight activity of Culicoides phlebotomus (Williston) Diptera: Ceratopogonidae) using three trapping methods ..

LORIMER, N. Long-term survival of introduced genes in a natural population of

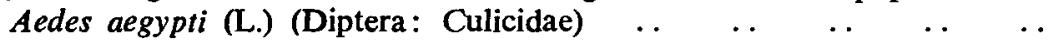

Sherwood, M. H., Greenway, A. R. \& Griffiths, D. C. Responses of Myzus persicae (Sulzer) (Hemiptera: Aphididae) to plants treated with fatty acids

Tyndale-Biscoe, M., Wallace, M. M. H. \& Walker, J. M. An ecological study of an Australian dung beetle, Onthophagus granulatus Boheman (Coleoptera: Scarabaeidae), using physiological age-grading techniques ..

Curtis, C. F. \& PAsteur, N. Organophosphate resistance in vector populations of the complex of Culex pipiens L. (Diptera: Culicidae) .. . . . 
Rajendran, S. \& Muthu, M. Post-fumigation productivity of Sitophilus oryzae (L.) (Coleoptera: Curculionidae) and Tribolium castaneum (Herbst) (Coleoptera: Tenebrionidae) exposed to acrylonitrile, adjuvants of acrylonitrile, acrylonitrile-adjuvant mixtures and other modern fumigants ..

Cox, P. D., Crawford, L. A., Gjestrud, G., Bell, C. H. \& Bowley, C. R. The influence of temperature and humidity on the life-cycle of Corcyra cephalonica (Stainton) (Lepidoptera: Pyralidae)

HAGGIS, M. J. Spatial and temporal changes in the distribution of eggs of Heliothis armiger (Hübner) (Lepidoptera: Noctuidae) on cotton in the Sudan Gezira ..

Okiwelu, S. N., Van Wettere, P. Maiga, S., Bouare, S. \& Crans, W. Contribution to the distribution of Glossina (Diptera: Glossinidae) in Mali ..

Morton, R., Tuart, L. D. \& Wardhaugh, K. G. The analysis and standardisation of light-trap catches of Heliothis armiger (Hübner) and H. punctiger

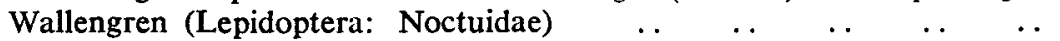

Hughes, R. D., Duncan, P. \& Dawson, J. Interactions between Camargue horses

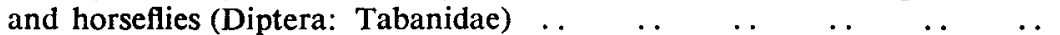

Williams, D. J. New records of some important mealybugs (Hemiptera: Pseudococcidae) ..

Cox, J. M. \& Williams, D. J. An account of cassava mealybugs (Hemiptera: Pseudococcidae) with a description of a new species

Vale, G. A. An effect of host diet on attraction of tsetse flies (Diptera: Glossinidae) to host odour $\ldots \begin{array}{llllll}\text {. . } & \ldots & \ldots & \ldots & \ldots & \ldots\end{array}$

Sternlicht, M., Goldenberg, S., Nesbitt, B. F. \& Hall, D. R. Further field trials of pheromone dispensers and traps for males of Prays citri (Millière) (Lepidoptera: Yponomeutidae) . .

Goldson, S. L. Reproductive diapause in the Argentine stem weevil, Listronotus bonariensis (Kuschel) (Coleoptera: Curculionidae), in New Zealand ..

Persson, B. Population fluctuations of the African armyworm, Spodoptera exempta (Walker) (Lepidoptera: Noctuidae), in outdoor cages in Kenya

Hole, B. D. Variation in tolerance of seven species of stored product Coleoptera to methyl bromide and phosphine in strains from twenty-nine countries

Dean, G. J., Jones, M. G. \& Powell, W. The relative abundance of the hymenopterous parasites attacking Metopolophium dirhodum (Walker) and Sitobion avenae (F.) (Hemiptera: Aphididae) on cereals during 1973-79

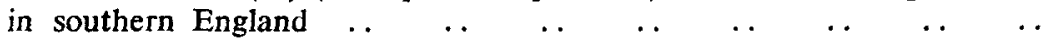

Farrugia, D. Three new Australian species of Goniozus Foerster (Hymenoptera: Bethylidae), and $G$. antipodum Westwood redescribed .. . . $\quad$.

Bradley, J. D. Marasmia patnalis sp.n. (Lepidoptera: Pyralidae) on rice in $\begin{array}{llllllllll}\text { S.E. Asia } & \ldots & \ldots & \ldots & \ldots & \ldots & \ldots & \ldots & \ldots & \text {.. }\end{array}$

Vogt, W. G., Woodburn, T. L. \& Crompton, G. W. Estimating absolute densities of the bushfly, Musca vetustissima Walker (Diptera: Muscidae),

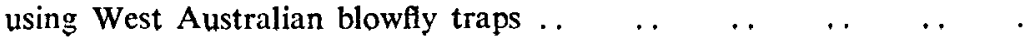


Pegram, R. G., Hoogstraal, H. \& Wassef, H. Y. Ticks (Acari: Ixodoidea) of Ethiopia. I. Distribution, ecology and host relationships of species

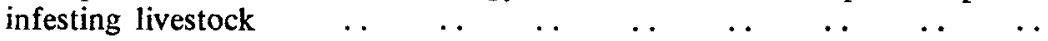

Suleman, M. \& Shirin, M. Laboratory studies on oviposition behaviour of Culex quinquefasciatus Say (Diptera: Culicidae): choice of oviposition medium and oviposition cycle $\ldots$

Ponr, A. C. Some new Oriental shoot-flies (Diptera: Muscidae, genus Atherigona)

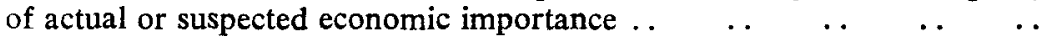

WILSON, A. L. \& TAYLOR, L. R. The effect of perforated polyethylene sheeting on the alighting behaviour of aphids (Hemiptera: Aphididae) and their

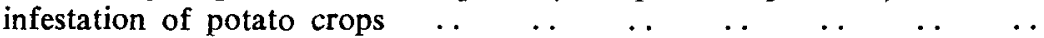

Marks, R. J., Hall, D. R., Lester, R., Neshitt, B. F., \& Lambert, M. R. K. Further studies on mating disruption of the red bollworm, Diparopsis castanea Hampson (Lepidoptera: Noctuidae), with a microencapsulated

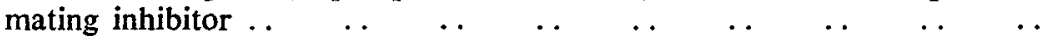

B. B. \& MUGGLEton, J. Inheritance of the ability of strains of Sitophilus oryzae (L.) (Coleoptera: Curculionidae) to breed on split-pea (Pisum

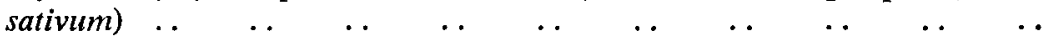

SMith, T. J. R. Some effects of three species of dung beetles (Coleoptera: Scarabaeidae) in south-western Australia on the survival of the bush fly, Musca vetustissima Walker (Diptera: Muscidae), in dung pads ..

Bigger, M. The relative abundance of the mealybug vectors (Hemiptera: Coccidae and Pseudococcidae) of cocoa swollen shoot disease in Ghana

Drake, V. A., Helm, K. F., Readshaw, J. L. \& Reid, D. G. Insect migration

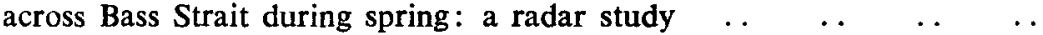

Mound, L. A. \& Palmer, J. M. Identification, distribution and host-plants of the pest species of Scirtothrips (Thysanoptera: Thripidae) . . . . .

LAMBERT, M. R. K. Observations on the laboratory take-off behaviour of the desert locust, Schistocerca gregaria (Forskål) (Orthoptera: Acrididae) ..

DAvies, J. E. Insecticide drift and reinvasion of spray blocks in aerial spraying experiments against Glossina morsitans centralis Machado (Diptera: $\begin{array}{llllllllll}\text { Glossinidae) } & \ldots & \ldots & \ldots & \ldots & \ldots & \ldots & \ldots & \ldots & \ldots\end{array}$

Disney, R. H. L. Megaselia sandhui sp. n. (Diptera: Phoridae), a pest of culti-

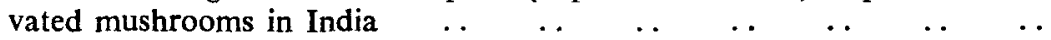

Hamann, H. J. \& IWANNEK, K. H. Sterilisation of Glossina palpalis palpalis (Robineau-Desvoidy) (Diptera: Glossinidae) by beta irradiation .. $\quad$.. 513

RYAN, L. Glossina (Diptera: Glossinidae) population growth rates $\quad \ldots \quad$. 519

Gray, J. S. The fecundity of Ixodes ricinus (L.) (Acarina: Ixodidae) and the mortality of its developmental stages under field conditions ... ..

\section{PART 4 DECEMBER 1981}

Hunter, D. M., McCulloch, L. \& Wright, D. E. Lipid accumulation and migratory flight in the Australian plague locust, Chortoicetes terminifera

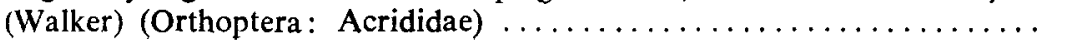


MAtteson, P. C. Egg parasitoids of hemipteran pests of cowpea in Nigeria and Tanzania, with special reference to Ooencyrtus patriciae Subba Rao (Hymenoptera: Encyrtidae) attacking Clavigralla tomentosicollis Stål (Hemiptera : Coreidae) ..

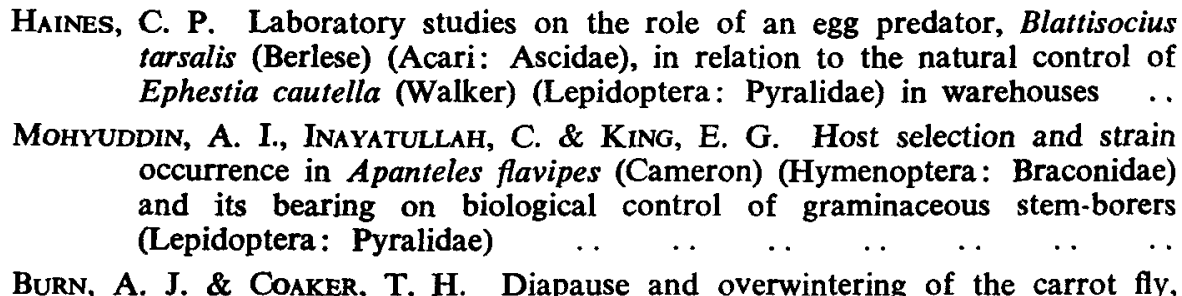

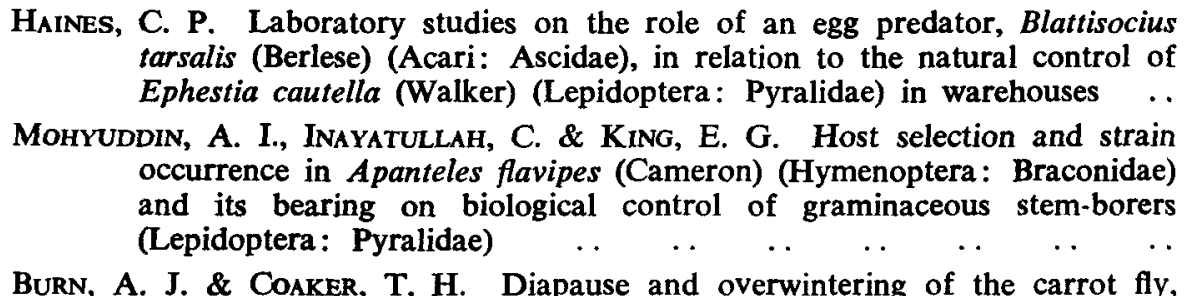

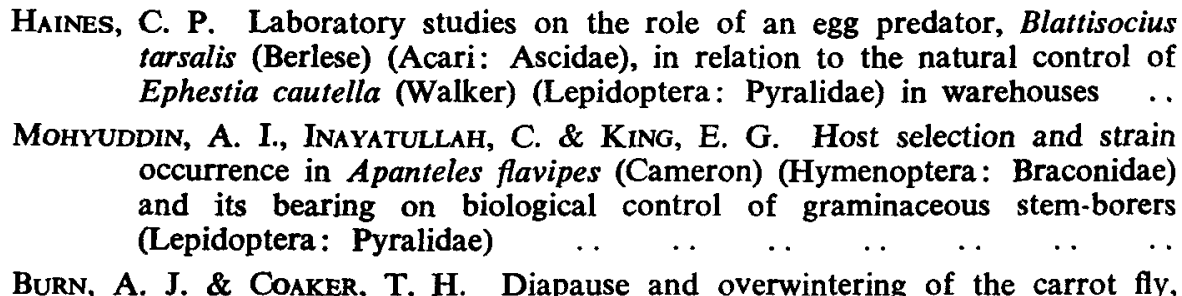

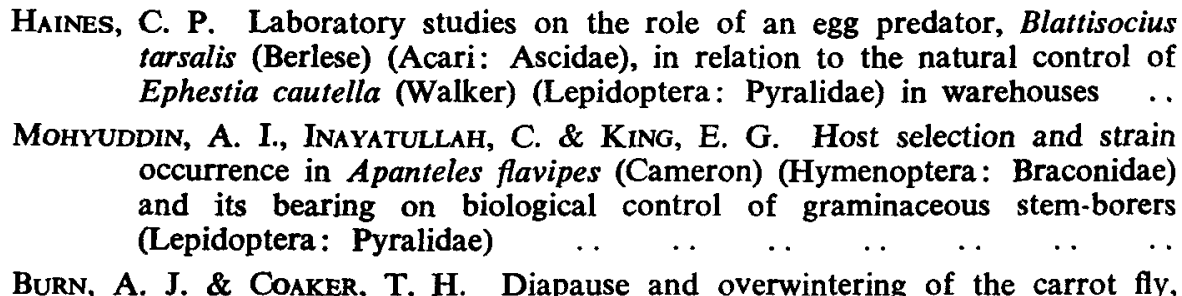

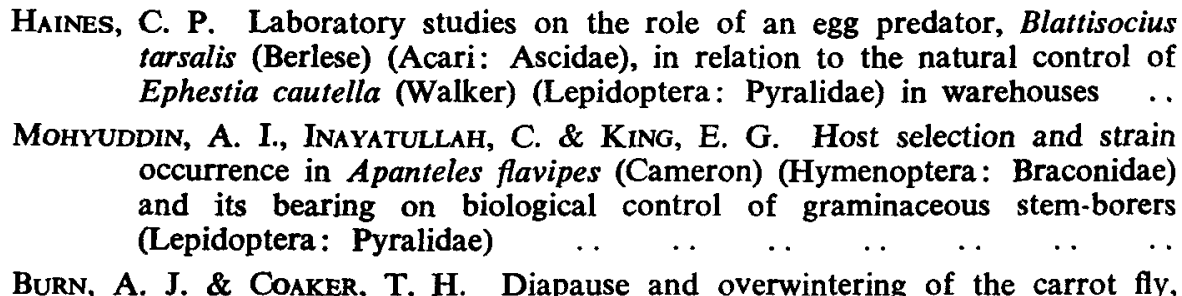

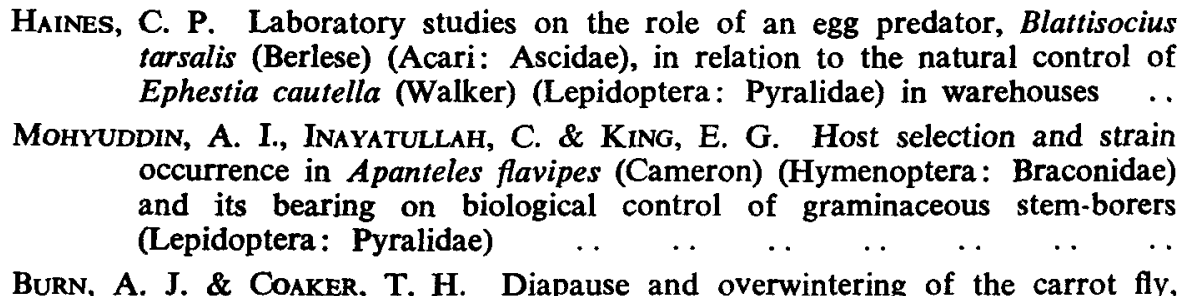

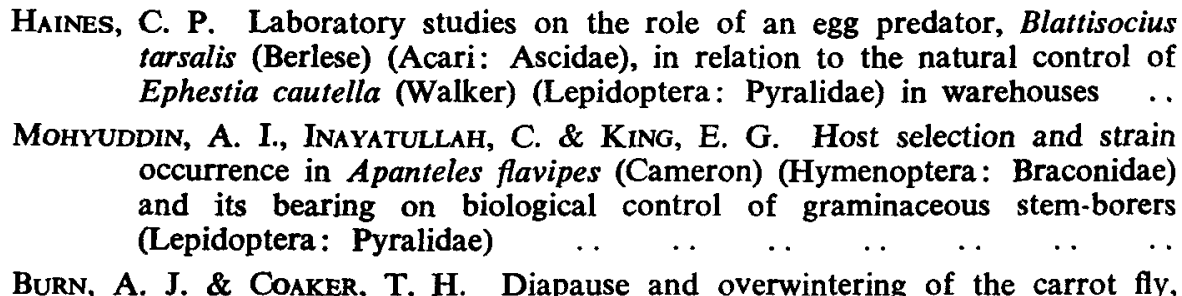

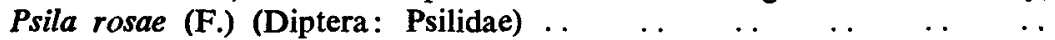

Haines, L. C. Changes in colour of a secretion in the reproductive tract of adult males of Spodoptera littoralis (Boisduval) (Lepidoptera: Noctuidae)

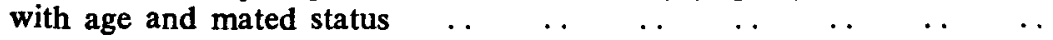

BaLL, S. G. \& LUFF, M. L. Attractiveness of Manitoba traps to the headfly, Hydrotaea irritans (Fallén) (Diptera: Muscidae): the effects of short-term weather fluctuations, carbon dioxide and target temperature and size ..

Jutsum, A. R. \& Cherretr, J. M. A new matrix for toxic baits for control of the leaf-cutting ant Acromyrmex octospinosus (Reich) (Hymenoptera: Formicidae)

Bradley, J. D. Anarsia achrasella sp.n. (Lepidoptera: Gelechiidae) on sapodilla (Achras zapota) in northern India and Pakistan $\quad . \quad \ldots \quad \ldots \quad \ldots$

Bowden, J. The relationship between light- and suction-trap catches of Chrysoperla carnea (Stephens) (Neuroptera: Chrysopidae), and the adjustment of light-trap catches to allow for variation in moonlight $\quad . \quad \ldots \quad \ldots$

KANNo, H. Seasonal variation in periodicity of mating behaviour in the rice stem borer, Chilo suppressalis (Walker) (Lepidoptera: Pyralidae) .. .

Lounibos, L. P. \& MunstermanN, L. E. Ecological and genetic separation of three sympatric species of Aedes (Diptera: Culicidae) from the Kenya coast . .

Ben-Dov, Y. A new species of Coccus (Hemiptera: Coccidae) from mango in Israel, and a redescription of $C$. gymnospori (Green) $\quad \ldots \quad$. $\quad$..

Duodu, Y. A. \& BiNeY, F. F. Growth, food consumption and food utilisation of Spodoptera littoralis (Boisduval) (Lepidoptera: Noctuidae) on four foodplants

SAMWAYS, M. J. Comparison of ant community structure (Hymenoptera: Formicidae) in citrus orchards under chemical and biological control of red scale, Aonidiella aurantii (Maskeli) (Hemiptera: Diaspididae) ..

Hodkinson, I. D. Status and taxonomy of the Trioza (Bactericera) nigricornis Förster complex (Hemiptera: Triozidae) $\ldots$. .

Tyndale-Biscoe, M., Wallace, M. M. H. \& Morton, R. Arthropod-induced mortality in immature stages of the bush fly, Musca vetustissima Walker (Diptera: Muscidae)

Maudlin, I., Green, C. H. \& Barlow, F. The potential for insecticide resistance in Glossina (Diptera: Glossinidae)-an investigation by computer simulation and chemical analysis

JAENSON, T. G. T. Ecology and behaviour of Glossina pallidipes Austen (Diptera : Glossinidae) in southern Kenya 
CONTENTS

$\begin{array}{llllllllllll}\text { NDEX OF AUTHORS } & \ldots & \ldots & \ldots & \ldots & \ldots & \ldots & \ldots & \ldots & \ldots & 717\end{array}$

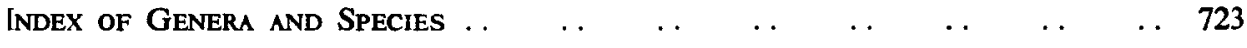




\section{Dates of Publication in Parts}

\begin{tabular}{|c|c|c|c|c|c|c|c|c|}
\hline $\mathrm{P}_{\mathrm{ART}} 1$, pp. 1-161 & . & . & $\cdots$ & . & $\cdots$ & . & . & 24 March \\
\hline PART 2, pp. 163-337 & . & $\cdot$ & $\ldots$ & $\cdots$ & $\ldots$ & . & . & 10 June \\
\hline ART 3. pp. 339-542 & . & $\ldots$ & $\ldots$ &. & $\ldots$ & . & .10 & September \\
\hline PART 4, pp. 543-734 & . & . & $\cdots$ & $\ldots$ & $\ldots$ & $\ldots$ & . 22 & December \\
\hline
\end{tabular}

\section{ERrata (Vol. 71)}

p. 247 , line 5 of abstract, for " $P$ " read " $P$."

p. 352, line 41 , for "leachi" read "leachii"

p. 467 , line 13 of text, for "darsalis" read "dorsalis" 